\title{
Intersections
}

Canadian Journal of Music

Revue canadienne de musique

\section{Finno-Ugric Rune Song Tradition Revisited: A Critical Discourse Analysis of Värttinä's "Äijö"}

\section{Yrjö Heinonen}

Volume 25, numéro 1-2, 2005

Northern Perspectives on Music and Culture

URI : https://id.erudit.org/iderudit/1013309ar

DOI : https://doi.org/10.7202/1013309ar

Aller au sommaire du numéro

Éditeur(s)

Canadian University Music Society / Société de musique des universités canadiennes

ISSN

1911-0146 (imprimé)

1918-512X (numérique)

Découvrir la revue

Citer cet article

Heinonen, Y. (2005). Finno-Ugric Rune Song Tradition Revisited: A Critical Discourse Analysis of Värttinä's "Äijö". Intersections, 25(1-2), 138-170. https://doi.org/10.7202/1013309ar
Résumé de l'article

Contrairement au très populaire rock finnois (HIM, Nightwish, The Rasmus), la musique folklorique contemporaine finnoise transmet la tradition finnoise et finno-ougrienne - sous une forme réinterprétée -, à des publics internationaux. Cet article explore cette transmission par une analyse de cas, en l'occurrence celui de Äijö, une chanson de Värttinä, la « marque par excellence » de la world music finnoise. L'analyse critique du discours offre un cadre unificateur permettant d'examiner l'apport des différentes traditions folkloriques musicales et des pratiques de la musique populaire occidentale dans l'élaboration de Äijö. Les données utilisées pour cette recherche sont essentiellement constituées de textes médiatiques publics représentant différentes étapes de la production, de la distribution et de la consommation de Äijö.
Copyright @ C Canadian University Music Society / Société de musique des universités canadiennes, 2005
Ce document est protégé par la loi sur le droit d'auteur. L'utilisation des services d’Érudit (y compris la reproduction) est assujettie à sa politique d'utilisation que vous pouvez consulter en ligne.

https://apropos.erudit.org/fr/usagers/politique-dutilisation/ 


\section{Finno-Ugric Rune Song Tradition Revisited:}

\section{A Critical Discourse Analysis of Värttinä’s “Äıjö"1}

\section{Yrjö Heinonen}

Contemporary Finnish folk music has been "hot stuff" in international world music circles for a decade or so. In this music-unlike in internationally successful contemporary Finnish rock (HIM, Nightwish, The Rasmus), techno (Darude) or rap (Bomfunk MC's) - the question is about transmitting aspects of Finnish and Finno-Ugric tradition to international audiences. In this paper, I will explore this transmission through “Äijö," a song by Värttinä, "the brand name" of Finnish World Music. The research material consists primarily of publicly available texts representing different stages of the transmission process: production (song writing, arranging, and recording), promotion (release announcements, concert ads), public reception (mainly reviews), and comments by fans (presented on the Official Värttinä Forum Website). The overall methodological framework is that of critical discourse analysis (Fairclough 1998, 1999).

\section{Värttinä, the Rune Song Tradition and the Question of Cultural IDENTITY}

Since neo-folk or world music tends to combine elements of various local (ethnic) folk music traditions on the one hand and of global popular music on the other, they might be seen as watering down "pure" or "authentic" local traditions. They can even be seen as examples of cultural homogenization or globalization. Stuart Hall has distinguished three hypothetical consequences of globalization on cultural identities $(2003,300)$ :

- national identities are being eroded as a result of the growth of cultural homogenization and "the global post-modern";

- national and other "local" or particularistic identities are being strengthened by the resistance of globalization;

- national identities are declining but new identities of hybridity are taking their place.

Värttinä's starting point has always been the Finno-Ugric tradition. Therefore, it seems obvious that the first category in Hall's hypothetical model is not relevant here; rather, the issue seems to be the establishment of a balance

1 The present article is part of a research project entitled "Historicity, Autobiography, and Nostalgia in Contemporary Finnish Popular Music" funded by the Academy of Finland. 
between the strengthening of particularistic (national, regional) identities and the forming of new hybrid identities.

Värttinä's career is commonly divided into two stages: the Old Värttinä (1983-1989) and the New Värttinä (1989 onwards). The group was formed in 1983 by Sari Kaasinen; the original concept was to recite Karelian poetry, sing and play kantele (the Finnish national instrument). Soon the group began to concentrate on playing and singing Karelian folk song, until they took as their common goal "to explore and revive Karelian / Finno-Ugric musical tradition and to discover new, more exciting ways of arranging and performing" (Värttinä Forum 2005). The New Värttinä (since 1989) diversified the group's repertoire "even further into Finno-Ugric territory, borrowing tunes, poems, songs and ideas from women's singing traditions of Setuland, Mariland, Ingria and other areas" (Värttinä Forum 2005). Their national and international breakthrough took place after the release of Oi Dai (1991); the timing was right, because the World Music boom had just begun. As of the early 1990 s, the group gradually began to favour newly written original compositions based on the ancient Finno-Ugric rune song tradition; the focus also shifted to a more "rock/pop" approach. To date (early 2006) Värttinä has released 11 albums; "Äijö" was originally released on Ilmatar (2000), their eighth album, and a live version of the same song was released on the album Live in Helsinki (originally 6.12.) the next year. In October 2003, Värttinä began writing the score for the stage adaptation of J. R. R. Tolkien's The Lord of the Rings in collaboration with composer A. R. Rahman. The World Premiere Gala took place on 2 February, 2006 at the Princess of Wales Theatre in Toronto.

The rune song emerged some 2500-3000 years ago in the culture of the proto-Finnic groups living near the Gulf of Finland. Characteristic of this singing tradition is the use of four-footed trochaic verse, alliteration and parallelism (saying the same thing twice in successive verses but in different words). The melodies of rune songs consisted of one or two phrases, usually in $4 / 4$ or $5 / 4$ meter and with a melodic range of a perfect fifth. This singing style remained vital throughout Finland until the $16^{\text {th }}$ century, after which it gradually disappeared, first in the south and west, and later elsewhere. It was replaced by the reki song - the name comes from German Reigenlied-which makes use of set stanza forms and end rhymes; meter is usually $2 / 4$ or $3 / 4$ and the melodic range is much larger than in rune songs. The rune song was preserved best in the Orthodox areas of Finland, Karelia and Ingria. (Asplund 1995; Asplund and Mettomäki 2000a; 2000b).

It has been said that the rune song was "the Finnish mother tongue in its musical manifestation, existing in parallel with the spoken one" (Asplund 1995, 23). It also played a crucial part in the construction of the Finnish national identity during the $19^{\text {th }}$ century. According to Hall $(2003,292)$, a national culture is "a discourse-a way of constructing meanings which influences and organizes both actions and our conception of ourselves." This 
discourse is told in the form of narratives, which include (but are not restricted to) the following five elements (293-295):

- the narrative of the nation, as it is told and retold in national histories, literatures, the media and popular culture

- the emphasis on origins, continuity, tradition and timelessness

- the invention of tradition

- a foundational myth: a story which locates the origin of the nation, the people and their national character so early that they are lost in the mists of, not "real", but "mythic" time

- the idea of pure, original people or "folk"

The narrative of Finland as an independent nation-state can be divided into the following four stages: (1) the pre-history from ca. $8000 \mathrm{BC}$ up to the $12^{\text {th }}$ century AD, (2) the Swedish rule from the 1150 s to 1809 , (3) the Russian rule from 1809 to 1917 and (4) independence since 1917. The rune songs were at the very core of the invention of the Finnish tradition since the Kalevala, the Finnish national epic, was based on this tradition. Lauri Honko has described the historical circumstances in the following terms:

The significance of the Kalevala is beyond dispute from the historical perspective. It was a major tool in the construction of a new national identity undertaken by students in Turku in the second decade of the $19^{\text {th }}$ century: K.A. Gottlund and Abraham Poppius from the province of Savo, A. I. Arvidsson and A. J. Sjögren from Häme [Tavastia], and others like them. They turned to folklore for a very special purpose. An identity had to be created for a nation inhabiting the backward territory between two major powers at a time when the 700-year tie with Sweden had been severed and a new alliance with Russia was only just being established. It was a situation marked by backwardness and fear, but also by dreams and hope. (Honko 2003)

The philosophical legitimacy for this was provided by German romanticism, particularly by Johann Gottfried von Herder's idea of the relation of Volkslied [folk song] to Volksgeist [folk soul]; according to him, the folk song was "a kind of mysterious, spontaneous product of the folk soul" (Karpeles 1973 , 1). A more practical point of departure had already been provided by Henrik Gabriel Porthan, who "had admired the innate talent, accurate memory and excellent command of their mother tongue of the nation's illiterate poets," as well as "the purity of their language, the pleasing originality of their phrases and their feeling for the beauty of their mother tongue" (Honko 2003; Porthan 1983 [1778], 70-71).

Given this background, the Kalevala was compiled and edited by Elias Lönnrot from a vast material of rune songs he collected mostly from the northern parts of Finnish and Russian Karelia during the 1830s and 1840s. Lönnrot's aim was no less than to compile an epic comparable to Iliad and Odyssey (Honko 2003). The first version, called the Old Kalevala, contained 
12078 lines and was published in 1835; the expanded version, called the New Kalevala (or just the Kalevala), contained 22795 lines and was published in 1849. The Kalevala quickly became "a national and linguistic cornerstone on which to lay the foundations of a frail Finnish identity" (Honko 2003). It was translated soon into Swedish and German, and the favourable statements by J. L. Runeberg (nowadays the Finnish national poet) and Jacob Grimm in particular "assured it a place not only in Finnish but in world literature as well" (Honko 2003). With Kalevala, "Herder's ideas came true in Finland: an epic created a nation" (Honko 2003).

The appropriation of the Kalevala by a learned elite in the service of nationalist ideology is what Bauman and Briggs $(1990,78)$ call the nationalization of culture, whereas considering the national epic as part of world literature (as Runeberg and Grimm did) is what they call the internationalization of culture. Both processes were active in the creation of Finland as a nation-state. Finland eventually declared independence on 6 December 1917, after the collapse of Czarist Russia and the founding of the Soviet Union. Given the historical significance of the Kalevala in the construction of the Finnish national identity, it seems relevant to relate later adaptations of the rune song tradition-including Värttinä's music-to questions of cultural identity.

\section{Critical Discourse Analysis}

Critical discourse analysis (CDA), a method developed by Norman Fairclough $(1998 ; 1999)$ for the analysis of public media texts, appears to be a promising approach in analyzing the production, distribution and consumption of such cultural products as Värttinä's songs. For Fairclough, the term "discourse" corresponds roughly to "dimensions of texts which have traditionally been discussed in terms of 'content', 'ideational meaning', 'topic', 'subject matter', and so forth." He prefers the term "discourse" since it is a particular way of constructing contents or subject matters, which "only enter texts in the mediated form of particular constructions of them" (Fairclough $1998,128)$. According to CDA, any specific instance of discursive practice can be seen simultaneously as text, discursive practice, and socio-cultural practice.

In cultural analysis, texts do not need to be linguistic: "any cultural artefact-a picture, a building, a piece of music-can be seen as a text" (Fairclough 1999, 4). Fairclough is aware of the dangers of obscuring important distinctions between different types of cultural artefacts and of making the concept of text nebulous by extending it too far. He adds, however, that the fact that "texts in contemporary society are increasingly multi-semiotic" is a strong argument for adopting a broader definition of "text" and mentions television as the most obvious example of "combining language with visual images, music and sound effects" (Fairclough 1999, 4). 
In linguistics, the purpose of textual analysis is to show "how texts selectively draw upon linguistic systems" (Fairclough 1999, 188) and this is done with respect to the following levels of texts (Fairclough 1998, 75-78):

- vocabulary (individual words)

- grammar (words combined into clauses and sentences)

- cohesion (linking clauses and sentences together)

- text structure (large-scale organizational properties of the text)

These levels not only apply as such to the analysis of song lyrics, but are also analogous to certain structural aspects of music. Rather than examining the issue of whether music is a language or not, it is sufficient to quote Kofi Agawu, who suggests that "music can be shown to exhibit features describable as linguistic (features of syntax, semantics, and semiotics)." The syntactic aspect is, perhaps, the most obvious since both musical texts and verbal texts are organized into discrete units or segments like phrases and larger sections (Agawu 1999, 141-46). It can be added that in song lyrics it is not just the semantic meanings of the words that count, but also-and often much more importantly - their musical quality: the sound (alliteration, assonance, rhyming) and the rhythm (prosody, foot). Writing lyrics to existing music or writing music to existing lyrics is an inter-semiotic translation, involving the translation of the semiotic capacities of a certain art form into another (Bauman and Briggs 1990, 76). Concerts, television and music videos add the visual dimension to this mixture; involving again an inter-semiotic translation from one modality into another.

Discursive practice refers to those activities and conventions according to which texts are produced, distributed and consumed. With respect to discursive practice, Fairclough distinguishes three further headings: force, coherence and intertextuality. In linguistics, "force" is linked to speech acts:

The force of part of a text (often, but not always, a sentence-sized part) is its actional component, a part of its interpersonal meaning, what it is being used to do socially, what 'speech act(s)' it is being used to perform (give an order, ask a question, threaten, promise, etc.). (Fairclough 1998, 82)

This sense of "force" coincides with the "illocutionary force" of a text, which has been applied to musicology most notably by Lawrence Kramer (1990). According to Kramer, the illocutionary force refers to "the pressure or power that a speech act exerts on a situation" $(1990,7)$. He also suggests that the illocutionary dimension exemplifies "a larger category of expressive acts through which illocutionary forces pass into general circulation" $(1990,9)$. This interpretation of "illocutionary force" links it to intertextuality.

While textual analysis explores how texts selectively draw upon linguistic (or musical) systems, intertextual analysis shows how they draw upon existing texts, genres, and discourses (Fairclough 1999, 188). In certain cases it makes sense to define a genre as "a rigid schema made up of stages, all or some obligatory, in a fixed order" (Fairclough 1999, 13-14). In other cases genres 
can be seen as "more flexible, unpredictable, and heterogeneous" (Fairclough $1998,14)$. In the latter case one can, indeed, speak about different degrees of intertextuality (Fairclough 1998, 118): sequential intertextuality (different texts or discourse types alternate within a text); embedded intertextuality (one text or discourse type is clearly contained within the matrix of another); and mixed intertextuality (texts or discourse types are merged in a more complex and less easily separable way).

The production process leaves "traces" in the text, whereas the interpretative process operates upon "cues" in the text (Fairclough 1999, 133). Fairclough distinguishes between three levels of explicitness of the "traces" (Fairclough 1999, 122):

- metadiscoursal level-aspects of discourse are overt discourse topics, frequently given explicit definition or explanation;

- discoursal level-discourse is still overtly present in describable features of texts;

- subdiscoursal level-discourse is an implicit interpretative resource that one needs to draw upon to arrive at coherent interpretation of the text. The interpreter uses certain features of the text as "cues" or, as Kramer has put it, as "hermeneutic windows." As for music, Kramer has distinguished between three types of hermeneutic windows, which correspond roughly to the three levels of explicitness suggested by Fairclough. The first, most explicit type is textual inclusion, which "includes texts set to music, titles, epigrams, programs, notes to the score, and sometimes even expression markings" (Kramer 1990, 9). The second type, citational inclusions, is "a less explicit version of the first, with which it partly overlaps," including not only "titles that link a work of music with a literary work, visual image, place, or historical moment" but also "musical allusions to other compositions" or "to the styles of other composers or of earlier periods" (Kramer 1990, 10). The third type, structural trope, is "the most implicit and ultimately the most powerful of hermeneutic windows" (Kramer 1990, 10); it acts "independently of received ideas about resemblances among various practices, discourses, and representation, and may even override obvious dissimilarities in style, scope, and context on behalf of shared ways of proceeding, of valuing, of presenting" (Kramer 1990, 12). In the following, I will use Kramer's term "hermeneutic window" (including textual and citational inclusions, structural tropes) in the same sense Fairclough uses the term "cue."

Socio-cultural practice can be examined on various levels. Fairclough $(1999,37)$ distinguishes between the following three levels: situational level (particular social event or action), institutional level (various social institutions), and the highest level of social structuring (the overall framework of society and culture). The term "order of discourse" refers both to "the ordered set of discursive practices associated within a particular social domain or institution" and to "boundaries and relations between them" (Fairclough $1999,12)$. Orders of discourse contain two kinds of relationships, "chain" 
relationships and "choice" relationships. "Chain" relationships are syntagmatic; they concern the way texts are circulated within orders of discourse: there are more or less settled chains of discursive practices within and between orders of discourse. "Choice" relationships, in turn, are paradigmatic; they refer to available choices in a given situation (Fairclough 1999, 13). The power to control discourse is conceptualized "both in terms of asymmetries between participants in discourse events, and in terms of unequal capacity to control how texts are produced, distributed and consumed (and hence the shapes of texts) in particular socio-cultural contexts" (Fairclough 1999, 1-2).

The way in which orders of discourse work in practice can be illustrated by comparing how folk music and popular music have been defined according to their different orders of discourse. The International Folk Music Council (IFMC) defined folk music at the São Paulo conference in 1954 in the following way:

Folk music is the product of a musical tradition that has been evolved through the process of oral transmission. The factors that shape the tradition are (i) continuity, which links the present with the past; (ii) variation, which springs from the creative impulse of the individual or the group; and (iii) selection, which determines the form, or forms, in which the music survives. (Karpeles 1973, 3)

According to an additional statement, this basic definition "does not cover popular composed music that has been taken over ready-made by a community and remains unchanged, for it is this re-fashioning and re-creation of the music by the community that gives folk music its folk character" (Karpeles 1973, 3; my emphasis). Popular music, in turn, can be-and has been-defined by reference to the process of its production, distribution (mediation) and consumption. The so-called gatekeeper theory defines the relations between the three factors followingly:

Artist and mass audience are linked by an ordered sequence of events: before it can elicit any audience response, an art object must first succeed in (a) competition against others for selection and promotion by an entrepreneurial organization, and then in (b) receiving mass media coverage in such forms as book reviews, radio station airplay, and film criticism. (Hirsch 1990, 128)

The "chain" and "choice" relations can be easily traced in both cases. However, the tripartite chain of continuity, variation and selection of folk music is substituted in popular music for another tripartite chain consisting of production, distribution and consumption. The question is not just about different concepts but about different practices. One basic difference is that in folk music the selection (choice) is made by the community and is subsequent to the performance; in popular music this is substituted for a preliminary selection made by various gatekeepers. 
Texts are thus open to multiple readings. During their production, distribution and consumption they are exposed to different reading positions, depending on the contexts of their reception (Fairclough 1999, 128). Fairclough $(1998,134)$ maintains that coherence, which he considers to be one aspect of discourse practice, "is not a property of texts, but a property which interpreters impose upon texts." This means that texts "postulate, and implicitly set up interpretative positions for interpreting subjects who are 'capable' of using assumptions from their prior experience to make connections across the intertextually diverse elements of a text and to generate coherent interpretations" (Fairclough 1998, 135). Different interpreters, including the producer of the text, may generate different but yet coherent readings of the same text. Interpretations can be "compliant, in the sense of fitting with the positions set up for them in texts" but they can also be "to a greater or lesser degree, and more or less explicitly, resistant" (Fairclough 1998, 136). Hall's (1980) tripartite distinction between dominant (hegemonic), opposite and negotiated interpretations is basically similar and can be used interchangeably with Fairclough's "more or less" compliant and resistant interpretations.

The following analysis attempts to explore the transmission and reinterpretation of Finno-Ugric tradition in Värttinä's “Äijö” in such a way that takes all basic components of critical discourse analysis into account: text ("Äijö" as a combination of music, lyrics and visual images), discursive practice (force, intertextuality, coherence), socio-cultural practice (situational level, institutional level, cultural level) and orders of discourse ("chain" and "choice" relations). The data consists primarily of publicly available media texts, including

- Ilmatar and 6.12./Live in Helsinki albums by Värttinä

- the official Värttinä biography by Kimmo Nevalainen (2001)

- Värttinä's official website (including Värttinä Forum)

- websites of record companies (BMG Finland, NorthSide) and retailers (for example, Amazon.com)

- reviews, feature articles, and interviews in various media (newspapers, magazines, webzines).

In order to enhance this data (Fairclough 1998, 227-28), I also interviewed Antto Varilo (composer), Kirsi Kähkönen (lyricist), and Risto Hemmi (recording engineer). The course of the analysis follows roughly the chronological order of the events. Accordingly, emphasis is placed on the "chain" relation dimension of the orders of discourse. Following Bauman and Briggs $(1990,78)$ one can distinguish between three levels of analysis: the "history" of performances (different versions) of "Äijö"; the "history" of different verbal statements concerning "Äijö"; and the small-scale (local, regional) and large-scale (global) "control" of the discourse. As for the latest, the emphasis is on the balance between particularistic (national, regional, ethnic) and global (popular culture, world music, world literature) viewpoints to "Äijö" 
and Värttinä's music in general. A summary of the overall form of the version released on Ilmatar is shown in Appendix 1.

\section{“ÄIjö"}

The making of a record involves a settled chain of discursive practices, including song writing, arranging, recording, mixing, mastering and packaging. In each stage certain choices are made and each choice adds something to the meaning of the song or record. The first creative impulse behind "Äijö" can be traced back to early 1998, when Antto Varilo figured out a riff, which he first thought to be suitable for the bass (Nevalainen 2001, 127). He describes the sources of inspiration behind the riff in the following words:

Often my songs (like "Äijö") come out during an intensive emotional state-maybe even in a trance-like state-when, I believe, I don't think consciously. So the starting point was a feeling, not any song I would have heard earlier. A threat, a supernatural event, a trance, fear and the Middle Ages are words with which I could lamely describe my feeling or vision at that time. (Varilo 2002)

I take this feeling of threat to be the basic illocutionary force of the song. At that time Varilo thought that the music contained nothing specifically Finnish or Finno-Ugric.

The riff was put aside for a year and a half, until September 1999, when Värttinä began to rehearse songs for their new album. Varilo transformed the riff into a supposedly vocal melody and added a contrasting section: "In the B-section I sought for an answer to the A-section; something different but complementary. I think it was a good idea to play it higher (It is indeed an effect used widely in music...)" (Varilo 2002). At this stage, he brought the song to rehearsals but was insecure of its reception: "It was so different (i.e. a 'simple' song based on a drone and a mere emotional state) that presenting it to such a group of musical geniuses was not too easy" (Varilo 2002). However, the song was accepted for further reworking and Kirsi Kähkönen was chosen to write the lyrics. She remembers that at the time the song was comprised of only the melody, played by Varilo on his guitar.

Writing lyrics to an existing melody can be seen as an inter-semiotic translation in the sense that it translates the semiotic capacities inherent in the melody into a verbal narrative fulfilling the stylistic criteria of the genre in question (Bauman and Briggs 1990, 76). Kähkönen describes her starting point in the following words:

The theme was found as I wanted to use as many " $y$," "̈̈," and "ö" letters as possible. Värttinä tours much abroad and these letters sound weird or even ugly - in the ears of foreigners. "Kylän äijä" (the village coot) was discovered because there are " $y$ " and "ä" letters in it. And it simply seemed to fit the melody. (Kähkönen 2002) 
The story (told in the B-sections) was newly written, although the idea of the healing rites following a spell was drawn from a well-known Finnish proverb: "If the sauna, liquor and tar do not help, the disease is lethal" (Kähkönen 2002). The spell itself was a later inclusion: "Riikka [Timonen] heard the spell when she was attending some course and when I brought the lyrics to rehearsals; she said that the spell would fit it well. She had it as a handout from that course" (Kähkönen 2002). Kähkönen took the spell home and started to rework it: "It began to develop around the [original] spell and then I took the rest out my own head ... approximately [the first] half of it was from that spell ... [up to] to 'et very miun verellä'" (Kähkönen 2002). The lyrics speak about "kylän äijä," a village coot; yet the title of the song is "Äijö": "I thought the title would be 'Kylän äijä' but someone said in rehearsals that it is “Äijö.' Others agreed and so it became "Äijö"' (Kähkönen 2002).

The lyrics not only made the feeling of threat inherent in Varilo's melody more explicit, but they also provided the basic structure for the overall form; they were not changed during the rehearsals. The music, in turn, underwent several changes. Varilo's original conception was to make a different Värttinä song: one which would be based on a drone, whose atmosphere would be threatening, and whose instrumentation would consist mainly of ethnic instruments (Nevalainen 2001, 127). Värttinä's music is, however, arranged in a "head arrangement" manner, which means that everyone is free to throw in suggestions concerning various aspects of the arrangement. In Varilo's own words:

I asked my friends to keep in one drone at a time. I wanted to keep "Äijö" to be a song that would not contain a million chords. Janne Lappalainen is a genius regarding chords and harmonies and he immediately came up with these wonderful alternatives. I just had to accept it, lovely chords!!! Luckily the drone feeling was kept, however... (Varilo 2002)

In addition to drone, the idea of using ethnic instruments was also kept. In the finished recording both jouhikko (an ancient Finnish bowed lyre) and cümbüs tanbur (a long-necked Turkish lute) were added to the standard line-up. The accompanying vocal part was written by Kari Reiman and Mari Kaasinen. At this stage, the most obvious references to Finnish or Finno-Ugric discourse include the use of jouhikko, lyrics based on excessive use of front vowels, the topic-including the scene (village, pine forest), the main character (wizened old man, obviously regarded as a village idiot), certain practices (snake spell, healing rites) - and the title. These references might be considered discoursal since they are overtly present in the song but there is (as yet) no explicit connection to Finnish or Finno-Ugric discourse.

Before entering the recording studio, Värttinä decided that they want a featured artist to perform the spell. In Kaasinen's words, "We had listened to real ones from archive tapes and come to the conclusion that clear-voiced girls from Rääkkylä could not produce such growling" (Rekinen 2000). They 
chose the distinguished Finnish rock singer Ismo Alanko, who did not hesitate to join in; his performance adds a "diegetic" dimension to the song (in film music terminology, "diegetic" sounds come from sources within the film's world or story space). The arrangement was finished only in the recording studio; last-minute additions included an overdubbed guitar part played by Varilo and various sound effects including the scraping of the piano strings.

For the earlier Värttinä albums, the songs had been chosen "democratically" within the group. Now it was agreed that producer Hughes de Courson would choose them "as a dictator" (Nevalainen 2001). Kari Reiman, the violinist of Värttinä, recalls: "We had 22 pieces composed before recording and Hughes selected 11 that he thought were strongest, those that suited his vision of the band and held together conceptually" (Roden 2000a). All songs released on Ilmatar were recorded at Finnvox studios during one week, from 22 to 28 November, 1999, and mixed at the Acousti Paris studios in January 2000. Three songs were, however, sent back to Finland to be mixed. Recording engineer Risto Hemmi declares the course of the events in the following words:

Everything was mixed in Paris in the first place. Some of the mixes deviated, however, from what was wished and the band wanted them to be remixed. "Kivutar" is entirely mixed by me. It is actually a demo, which I have mixed alone. Then there are "Itkin" and "Äijö," which are more like works and that's why the band wanted them to be remixed. Itkin was mixed with Pekka Lehti and "Äijö" I mixed with Antto Varilo.

In "Äijö," the entries and the fading of different elements were changed. Now I don't remember what the original French mix was like, but the changes concerned the entries and the fading of different parts in the very beginning. As the composer, Antto knew what he wanted and said what [should come] in and when. (Hemmi 2002)

What Varilo wanted was to increase the threatening feel of the song in the mix: "The original energy and feel of threat-already felt in playing [the song] - was not manifest in Hughes's mix. He complained too, and asked us to try it ourselves" (Varilo 2002). According to Varilo, he and Hemmi encouraged one another "in giving more emphasis to the feel of threat in the spell" (Varilo 2002). When this was done, the team was satisfied with the end result.

The end result certainly manifests mixed intertextuality. On the level of phrase structure, "Äijö" shares certain similarities with rune songs. Both the $A$ - and B-sections are based on varied repetition of a single, one-bar line. The poetic meter of the lines is not four-footed trochaic (consisting of 8 syllables), as is usual in rune songs; instead, each line of the A-sections consists of 9 syllables while each line of the B-sections consists of 12 syllables. Alliteration and parallelism are favoured. In "Äijö," there is a special kind of alliteration based on an extensive use of front vowels ("y," "ä" and "ö"). Parallelism, in turn, is manifest in expressions like "viinalla valeli, pirrulla pesevi" ("washed 
it with liquor / poured poor spirit over it" and "päätä pölkyllensä, pahan pirulaisen / kieron kastiaisen kurkun kirvehelle" ("wanting to put that wily devil's head on the block / to take an axe to its slithery neck").

The musical structure of the phrases resembles certain Ingrian rune songs collected and categorized by Armas Launis (1910). The melody of the A-section corresponds to Launis's first minor type, in which the range of the tones appearing on strong beats falls between the dominant and the tonic (or second) above it. The melody of the B-section, in turn, corresponds to the second minor type where the range falls between the tonic and the fifth (or sixth) above it. The rhythmic structure of each bar in "Äijö" corresponds to the one which Launis formalized as $6(3+3)$; that is, six beats divided into two units of three. Both sections are built in such a way that the basic phrase is followed by its variant, after which this two-phrase structure is repeated; thus, the structure of the A-section is a-a'/ a-a' while the structure of the B-section is b-b' / b-b'. This formal principle is very common in Finnish, Karelian and Ingrian rune song tradition.

In contrast, the large-scale text structure deviates notably from that of Finno-Ugric rune songs. Whether these songs were short (just a couple of verses, as in some lyrical songs), long (as in many epic poems) or something in between, the large-scale organization was achieved by adding coupled verses one after another. There was no set stanza structure. The large-scale structure of "Äijö," in turn, basically follows the verse/chorus form adopted from Western popular music, consisting of an appropriate amount of verses and choruses, an instrumental/vocal intro and instrumental interludes. Thus, the "Finnish" or "Finno-Ugric" small-scale structure (phrases, linking phrases together) is, on the level of the large-scale organization, embedded within a generic schema "borrowed" from popular music, whereas the spell-actual and manifest borrowing from the ancient runes-is embedded within this intertextual mixture. "Äijö," then, combines several of Fairclough's intertextuality types within itself.

The story told in the verses preceding the spell bears some resemblance to the $26^{\text {th }}$ poem of the Kalevala (entitled "Origin of the Serpent"), in which Lemminkäinen travels uninvited to the Northland (Pohjola), encounters a viper and performs a snake spell. The spell itself is divided into two sections: the origin (or cause of the problem) and the curse (or exorcism). In ancient shamanistic practice these sections served different functions; knowledge of the origin of the troublemaker was thought to be the key to commanding it, whereas the curse was thought to drive it out once and for all. In “Äijö's" spell, the section which deals with the cause (origin) is taken from an original spell, while the curse section was newly written by Kähkönen. As can be seen in Appendix 1, the beginning of the curse section is repeated before returning to the song. In fact, the spell quoted in "Äijö" shares many identical (or almost identical) verses with the $26^{\text {th }}$ rune of the Kalevala. Four of these verses can even be heard in the finished version of "Äijö." Verses 3-4 ("maan nuora, 
kanervakarva / maan on sykkä synnyntäsi," translated freely as "Cord of earth, hair of heather / Earth it was who first uncoiled you") correspond to the verses 761-62 of the $26^{\text {th }}$ rune, whereas verses 5-6 ("tiijä sykkä synnyntäsi / maan kavala kasvantasi," translated freely as "This thine origin, O Serpent / This thine ghastly provenance") correspond to the verses 691-92 of the same rune.

As pointed out by Kramer, titles may be illuminative hermeneutic windows into the meaning of a musical work. In old Finnish, "Äijö" is a synonym for "äijä" (old man). It has, however, other meanings including "big," "father," "god," and "thunder." In the $42^{\text {nd }}$ rune of the Kalevala, entitled "Capture of the Sampo," "Äijö" is used in a sense related to those terms. In this rune Väinämöinen captures the Sampo from Pohjola and Louhi, hostess of Pohjola, conjures up Iku-Turso (a kind of sea-monster) in order to wreck Väinämöinen's boat. The words she uses are "Iku-Turso, Äijön poika" (translated as "Iku-Turso, son of Old-age"). In this rune, "Äijö" (Old-age) is the father of a sea-monster. Whereas in modern Finnish "äijä" can refer to almost any male person, "Äijö" (which does not belong to modern Finnish) still carries the old meanings, which is why it forms a more forceful framing of the song.

When asked about the above similarities, both Varilo and Kähkönen reported that the Ingrian tradition was never their starting point in the writing of the melody or the lyrics of "Äijö." Moreover, Kähkönen noted that the story of "Äijö" was not-at least consciously-influenced by the $26^{\text {th }}$ poem of the Kalevala; she was indeed surprised to hear about the exact similarities between "Äijö's" spell and the spell in Kalevala's $26^{\text {th }}$ poem. I take this to be the authoritative interpretation of the issue and do not see any reason to challenge it. Thus, these similarities are subdiscoursal rather than discoursal; they can be taken as implicit interpretative resources upon which one can draw and end up with a coherent interpretation. The similarities are not irrelevant or simply coincidental; apparently Varilo and/or Kähkönen did not consciously draw from certain particular Ingrian songs or from the Kalevala's $26^{\text {th }}$ rune-they just used patterns that are commonly used in the Finno-Ugric rune tradition. In this sense, I consider both the Ingrian song family and the $26^{\text {th }}$ rune of the Kalevala to be illuminative hermeneutic windows to the rich intertextual reservoir of meaning in "Äijö."

\section{ILMATAR}

The release and marketing of a record form another chain of discursive practices, including packaging, promotion, distribution (literally: the distribution of the actual records to retailers; more generally, the airplay, performances and interviews on radio and TV etc.) and public reception (interviews, feature articles, reviews). Again, choices made in each stage change and reinterpret the "original" meaning of the music. The producer's point of view might be called "authoritative" in the sense referred to by Bauman and Briggs $(1990,77)$, and is "grounded, at least in part, in the knowledge, ability, and 
right to control the recentering [recontextualization, reinterpretation] of valued texts." The promoter's task is to publicize compliant readings of the music that are assumed to be attractive for the target audience. Reviewers, in turn, are expected to give not only compliant but also negotiated or resistant (opposite) readings of the music.

As suggested earlier, the title is a powerful "hermeneutic window" into the meaning of a song or an album; with respect to the latter, it also provides a more general framework within which the individual songs on the album are interpreted. Värttinä's eighth album is entitled Ilmatar, the Goddess of Air in the ancient Finnish mythology. The producer, Hughes de Courson, was largely responsible for the musical conception of the record, though it was Kari Reiman who made Ilmatar a concept album:

The concept of the album was already outlined before we found the name for it. After recording was completed, I was browsing through old runo [folksong] collections and happened upon a song about the creation of the world. The story, the characters, the feeling, everything about it seemed to compliment the music we had made, and Ilmatar ("Goddess Of Air") seemed to be a perfect name for the album. Other elements in the runo-the characters Kokko and Vihma for example-could easily be interpreted to represent the creative process of our music, in particular the runo concept of the last three albums. (Roden 2000a)

As a finished product, Ilmatar consists of a $C D$, a plastic case and a 16-page booklet containing the Ilmatar poem and the lyrics to all songs; the cover of the booklet also works as the cover of the entire package. The English translation of the poem goes as follows:

Came an eagle, Kokko, from the dawn of Air, underneath the skies. Over the sea she soared, seeking a nesting place. Ilmatar, Goddess of Air, the beautiful Virgin, lifted her knee from the sea. Kokko laid six golden eggs and a seventh made of iron on the knee of the Virgin Goddess. Came a cold wind, a fierce Vihma, seizing the eggs, plunging them into the waters. Came the pike, Hauki, the seadog, swallowing the eggs. Kokko struck once, struck twice and split Hauki's stomach freeing the eggs, breaking them into pieces. What was the lower part of the eggs became Mother Earth, made of iron. The upper part became the sky, made of brass. The yolk of the eggs became the sun. The white of the eggs the moon and all the fragments of the eggshells became the stars. (Värttinä 2001a)

The quotation includes the titles of the two Värttinä albums preceding Ilmatar - that is, Kokko (1996) and Vihma (1998). These three albums form a kind of trilogy based on Finno-Ugric mythology. The booklet cover of Ilmatar represents the eagle Kokko flying "underneath the skies, over the sea" (only the wing feathers are shown). The song lyrics are illustrated with photos of the band members, various pictures representing bones of the pike (many of them with fins and one with a tail), and the skeleton of a snake. The Ilmatar 
poem is placed on the left side of the first double page; the right side contains the running order of the songs. The left side is illustrated with the eagle's wing feathers and the right one with a pike's lower jawbone. "Äijö's" lyrics are placed on the center pages (right side); the top of the left side is illustrated with a picture of a pike's upper jawbone. The spell is separated from the lyrics and placed on the right side of the last double page, the left side containing the names of the musicians and their instruments. On the bottom of this double page is a picture of the skeleton of a snake. This special treatment framed "Äijö" as a kind of theme song for the entire album.

The relation of Ilmatar to the Kalevala deserves a brief exploration. First, there are obvious affinities between the quoted poem and the Ilmatar episode in the first poem of the Kalevala. The Ilmatar poem quoted in the booklet also contains themes from other poems of the Kalevala (e.g. poems 19, 47, and 48). Second, the pike's jawbone refers not only to the pike Hauki mentioned in the Ilmatar poem but also to Väinämöinen's kantele in the Kalevala; this five-string plucked zither, with which Väinämöinen held sway over nature, was made of a pike's lower jawbone. Third, as mentioned earlier in this article, certain lines (verses) of "Äijö's" spell can be found as such in the snake spell from the $26^{\text {th }}$ rune of the Kalevala. Although overtly present, these references to the Finnish national epic are not made explicit in the album package. In Fairclough's terms, references to the Ilmatar poem and Finno-Ugric rune tradition in general are metadiscoursal while the linkages between the album and the Kalevala are subdiscoursal interpretative resources.

Ilmatar was released in Finland, Europe and Japan in May 2000 by BMG (Wicklow). In Finland the day of release was 2 May. BMG updated the biography of Värttinä available on their www-pages and framed the album by associating the Ilmatar myth with the musical contents of the record:

ILMATAR is the goddess of air in old Finnish rune songs and Ilmatar is strongly present on the record, in the title of the record, as well as in its sonic world. The songs on the record vary from the tender and beautiful "Milja", sung by Mari Kaasinen, to the wild and gloomy "Äijö", featuring Ismo Alanko as a shaman. The vielle à roue of Gilles Chabenat gives additional color to many tracks on the record. All in all, ILMATAR is a record, which will shock and surprise the old and faithful followers of Värttinä as well as the new friends of Värttinä's music. (Click2Music 2001)

The release of Ilmatar was noted by the Finnish music press in a number of reviews and feature articles. Most reviews mentioned "Äijö," many of them with a reference to Finno-Ugric shamanism. On the day of the album's release, Helsingin Sanomat, Finland's leading newspaper, published a lengthy reportage on Värttinä. It included a review of Ilmatar by Pirkko Kotirinta, whose comments on "Äijö" emphasized the song's force:

In "Äijö", the sound of the female singers meets the earthy, wheezing spell of Ismo Alanko, and lo and behold: the Ugric Ur-Kraft is more tangible 
than ever. The combination of the clear Värttinä sound and Alanko's deep growling works light years better than the attempt to combine the Värttinä sound with Tuvan throat-singing on Vihma. (Kotirinta 2000)

As for the international reception, Chris Nickson paid attention to the mythical dimensions of both Ilmatar and the two albums preceding it: "Ilmatar concludes a Finnish-myth-trilogy that began with 1996's poppy Kokko and continued with the rootsier Vihma in 1998" (Nickson 2003a). In another review he linked the album even more explicitly to Finnish mythology, to the rune song tradition and to Värttinä's history:

Ilmatar, named for a Finnish goddess of air, delves into folklore, mythology, and, of course, the runo songs that are the cornerstone of the band, and presents them in a manner that combines all the facets of the group's history - as traditionalists, sonic adventurers, and peeking into the new. (Nickson 2003b)

One could say that Nickson's reviews are compliant with the "authoritative" interpretation (Värttinä), as well as with the record company's "framed" version of it.

Christina Roden, who reviewed Ilmatar in The Village Voice and RootsWorld, threw in several intertextual references to various styles, performances and songs. For example, she described the vocal sound of the group in the following words: "There is a shrill, dissonant, almost Balkan edge to their singing, often grounded by a male voice drone not unlike the inexorable basses of Russian liturgical music." As for the instrumental accompaniment, she notices that the "fiddles make fateful, raking string chords straight out of "Eleanor Rigby" (obviously she means "Kivutar" although she does not mention it by name). With respect to songs mentioned by name, she found that "Lieto" resembles at times "Irish, Galician and even Medieval dance styles" while "Sanat" "features a slouching bass line that Nina Simone would feel right at home with" (Roden 2000b).

Andrew Cronshaw, who reviews Ilmatar for Folk Roots, is much more careful in his associations: he mentions the Bulgarian women's choir-an association to which I will return in the next section-and relates "Äijö" to Hedningarna's style:

On Aijo, with its incanted spell from popular Finnish rock singer Ismo Alanko, there's what might be viewed as a touch of Hedningarna style approach, but it's just a path-crossing in the evolutionary expansion of natural and exciting ways to interpret this primal, insistent runo-music that has also been one component of Hedningarna's song-material. There's no polska or halling here, it's Finno-Ugrian, not Scandinavian, and in core instrumentation (which on this track features jouhikko, the horsehair-stringed, bowed lyre) as well as in general sound and in essence, the two bands are on different roads. (Cronshaw 2000) 
While both critics provide intertextual references, they use them differently. Roden makes several references to various styles, performers and songs but does not provide any grounds for the linkages. Cronshaw, in turn, begins with establishing an intertextual reference, then sets it under a close examination, and eventually denies the (analytic) value of the reference. Cronshaw operates on metadiscoursal level and his approach appears to be more "critical" than Roden's. Her references are discoursal in the sense that they are overtly present in her text as citational inclusions; one can agree or disagree with her only if one is familiar with the tradition, artist or song in question and is capable of understanding her viewpoint. I would say that her associations are illuminative as hermeneutic windows: when she speaks about "Eleanor Rigby," I know what she means (this is evident from the mere fact that I know which song she links with "Eleanor Rigby"); when she mentions Nina Simone, I understand her once again.

\section{LIVE IN HELSINKI (6.12.)}

Both touring and making music videos are parts of the promotion, distribution and consumption of records and individual songs. The meanings of the songs are also continually negotiated during this process, which concerns not only the distribution and consumption but the production as well. "Äijö" quickly became one of Värttinäs's most impressive stage numbers. Since each member of the band had her or his own part in the performance and because they did not want to use visiting musicians, the arrangement had to be simplified to correspond to the "standard" line-up. The most obvious change was, of course, substituting Kähkönen for Alanko as the performer of the spell. Her own recollection of stepping into Alanko's boots goes as follows:

Everyone does [performs] it in her or his own style. Well, surely it felt like [my] own since I had written the text. First I was just afraid of blackouts and of forgetting the words during a performance-and it indeed came out slightly differently in different performances-but then I just found a rhythm to it, which fit it well. (Kähkönen 2002)

There were other changes as well. The noisy opening of the intro was now stretched to last more than half a minute. The vocal intro was also arranged differently: not only did female voices substitute for Alanko's growling, but the entries of the vocal parts were also changed to begin more synchronically with the instrumental accompaniment.

On 6 December, the Independence Day of Finland, Värttinä played a concert at the Savoy Theatre in Helsinki. Some group members, Pekka Lehti leading the way, had decided to record the concert for the coming live album. Since the aim was to record as authentic a document of the performance as possible, Lehti did not tell the singers about the recording. The performance was successful, and in early 2001 Värttinä decided that the live album would consist entirely of songs recorded at the Savoy. This was partly due to the fact 
that Riikka Timonen was about to leave the group; hence the last concert recording would have extra merit as a document of the end of an era.

Värttinä also decided to make a music video to be included on the album as a bonus track. The choice fell on "Äijö." The performance was videotaped at Nosturi, Helsinki. Värttinä performed playback onto the soundtrack recorded at Savoy on 6 December 2000, which meant that Johanna Virtanen was lip-syncing to Riikka Timonen's vocals on the video. In Autumn 2001 Värttinä completely renewed their www-pages. The site now contained a special page for the "Äijö" video, with the possibility of downloading the video onto the hard disc of one's own computer. The "official" or "authoritative" framing of the video, presented on the www-page, goes as follows:

Värttinä's third video is the live version of "Äijö," originally appearing as a studio recording on their last album Ilmatar. The song, composed by Värttinä guitarist Antto Varilo, with lyrics by Kirsi Kähkönen, is one of the band's most powerful stage pieces. It tells the story of a crazy old coot "äijö" who is bitten by a snake and resorts to casting an ancient spell to rid himself of the poison and the snake's very existence. On the Ilmatar album, distinguished rock singer Ismo Alanko guests as "Äijö," while on stage and in the video, Kirsi screeches out the spell with magnificent effect. The "Äijö" video, also a bonus track on the $6.12 \mathrm{CD}$, features new Värttinä singer Johanna Virtanen, replacing Riikka Timonen and percussionist Jaska Lukkarinen, replacing Marko Timonen. (Värttinä 2002)

This framing emphasizes the illocutionary force of "Äijö," both by acknowledging it as "one of the band's most powerful stage pieces" and by highlighting the "magnificent effect" with which Kirsi Kähkönen "screeches out the spell."

The album was titled 6.12., the recording date. More important, however, is the fact that the title is also a metonymic substitution for Finland as an independent nation-state. In a sense referred to by Kramer $(1990,10)$, it is also a citational inclusion linking the album with a certain historical moment-namely with the declaration of independence by the parliament of the autonomous Grand Duchy of Finland on $6^{\text {th }}$ December, 1917. Whereas the contents of the album link it with the Finno-Ugric rune song tradition that had "created the nation" in a Herderian sense, the title links it with the most important aspect of any nation-state: its independence. As a whole, the album can be seen as an extremely powerful expression of Finnish national identity.

In Finland the album was released in early September. BMG's release announcement ( 3 April 2001) framed the album by unabashedly referring to national identity, as suggested by the title:

6.12. is a great praise to the Finnish tradition, to Finnish music, and to the Finnish attitude. During their career Värttinä have won great success around the World with their uncompromising style. They have performed at small clubs and at big festivals, conquering their audiences regardless 
of the language barriers or cultural differences. On the new record Värttinä performs before a live audience at the Savoy Theatre in Helsinki on $6^{\text {th }}$ December in 2000. Included are the best songs of the band and, as an extra bonus, a video of "Äijö." (BMG 2001)

This framing was not, however, included in the international distribution or reception of the album. In the US, NorthSide released the album on $12 \mathrm{March}$, 2002, now re-titled Live in Helsinki. This new title substituted the date for the place of recording. Although the release announcement indicated both the time and place of the recording ("Recorded live in concert December 6 $6^{\text {th }}, 2000$, Helsinki, Finland") there was no reference to the Independence Day of Finland.

This deserves a comment or two. It is a very common practice to use the name of the place of performance (hall or club, city, country) in the title of a live album, often in the form "Live in ..." or "Live at ..." Certain places are used frequently as this kind of citational inclusions. Both Donovan and Amon Düul II (a German "Krautrock" group) have released Live in Tokyo, while Deep Purple released a live album called Made in Japan. Elvis Presley and Alan Jardine have released Live in Las Vegas, one of Céline Dion's live albums is entitled A New Day ... Live in Las Vegas and Sarah Brightmann has entitled hers Live from Las Vegas. There are certain favourite venues as well: for example Carole King, Benny Goodman, Miles Davis and Shirley Bassey have all released an album called Live at the Carnegie Hall; the Allman Brothers and Jimi Hendrix both have an album called Live at the Fillmore East. The Beatles, of course, released Live at the Hollywood Bowl. So, the North-American title of Värttinä's live album follows a well-grounded convention.

Another issue is the reference to Helsinki; the name of the capital city is connected with Finland and Finnish people in much a broader sense than would be possible with a mere reference to the nation's Independence Day. Helsinki is an important place for Värttinä, too. Värttinä came originally from Rääkkylä, Northern Karelia; however, this is only true of the Old Värttinä. The New Värttinä was founded in 1989 in Helsinki. This city and particularly the Sibelius Academy has been their base since then (most of the members have studied and/or taught at the Sibelius Academy). Moreover, the Savoy Theatre has been one of their favorite venues as far as live performances in Finland are concerned. Given this background, Live in Helsinki is certainly a suitable title for Värttinä's live album; and in any case, the new title was adopted with the group's approval.

With no specific reference to the Finno-Ugric tradition as such, the mixed intertextuality of the music left room for imagination and loose associations. Bob Tarte's review, published in the Miami New Times (2 May, 2002), is worth quoting in this regard.

Imagine 1970s Swedish pop group Abba at full ecstatic tilt in the middle of a climactic chorus. Establish that as the baseline from which Susan Aho, Mari Kaasinen, Riikka Timonen, and umlaut-blessed Kirsi Kähkönen begin, add dissonant harmonies, Eastern modalities, then dose the quartet 
with angel dust-fallout from real angels, not the drug-for an inkling of the women's ilk. Songs on Live catch Värttinä producing the most elementally pagan sound you'll encounter anywhere in pop, a snarling, guttural, estrogen-charged aesthetic arching back to archaic pre-cataclysmic days before the earth's poles flip-flopped, when the matriarchy ruled. On disc opener "äijö" a quartet of she-devils emerges hissing from a cave ... even the brothers of Grimm wouldn't dare to tell. It's standard Finnish, but Kähkönen chose the most tortured phonemes she could find to give the poetry extra invective. (Tarte 2002)

This review also contains two intertextual references that I wish to discuss in more detail: ABBA and the brothers of Grimm. Comparing Värttinä to ABBA is nothing new. In fact, the characterization of Värttinä as a mixture of Les Voix Bulgares and ABBA has circulated in the music press for several years. This comparison was probably presented for the first time in 1993, during Värttinä's first US tour (Nevalainen 2001, 52). Indeed, in Musician (September 1993,79 ) the reviewer states that "what's front and center here is a female vocal quartet whose spine-tingling harmonies simultaneously bring to mind Les Voix Bulgares and ABBA" (NorthSide 2004). In Germany the slogan "Bulgarische Stimmen treffen ABBA" [Bulgarian voices meet ABBA] has been used in advertising Värttinä's tours, including the 1998 Vihma tour (Nevalainen 2001, 66; DFG-NRW 1998) and the tour in August 2001. It has also been referred to in reviews concerning Värttinä's 2002 album, $i k i$, by Stefan Franzen (2003) and Dominique Leone (2003).

The comparison is made with both opposite and negotiated readings. Cronshaw complains that the whole mess began when "an occasional, clotheared reviewer after a superficial listen compared Värttinä to Les Voix Mystères" (2000, 54). Cronshaw considers the comparison "ridiculous" (2001, 43). Another reviewer takes the instrumental accompaniment into account: "ABBA meets Fairport Convention and La Mystere [sic] des Voix Bulgares" (Graham 1996). Another source (Indigo 2004) describes the Värttinä sound as "eine Rockversion der bulgarischen Chorgesänge" (a rock version of Bulgarian choir singing). John Cho puts it in the following way:

How do I describe the Värttinä sound? First try: Wall of estrogen. Värttinä, in its current incarnation, is fronted by four women singers. And it is their voices that dominate. One chord blast from them will immediately convince you that the standard Western European bel canto vocal style never made it across the Baltic. The absolutely unwavering, vibratoless attack of these women have more in common with Bulgarian women's choirs than with, say, ABBA from neighboring Sweden. Their singing is bracing and energizing (one could almost imagine the vocal technique applied to punk rock), but also clean and pure in that the harmony locks in very tightly due to the lack of resonant overtones and pitch fluctuations. (Cho 1996)

"Wall of estrogen" is, of course, a rephrasing of "wall of sound," a concept first associated with producer Phil Spector in the 1960's. However, this 
concept has also been associated with Värttinä at least by Jazziz magazine (October 1995, 42), which describes Värttinä's sound as "a distinctive 'wall of sound' without much studio trickery" (NorthSide 2004). "Wall of estrogen," then, refers both to the apparent "girl power" of the front line per se and to the loud and shrill sound they create. Certainly the "wall of sound" produced by strong female singers and professional male backdrop is one thing common to both ABBA and Värttinä.

The reference to the tales of the Grimm brothers in Tarte's review requires further background. Chris Nickson had already tackled a somewhat similar topic in his review of Ilmatar in the AMG (All Music Guide): "Given its subject matter, it's not too surprising that it's an album of magic-even down to the spell incantation of 'Äijö,' while the keening voices and harmonies of the four singers tear through the air like lovely witches" (Nickson 2002). (It must be remembered here that on Ilmatar, the spell was recited by Ismo Alanko, not the "lovely witches" of the female front.) Another reference to witchcraft had already been made by Wif Stenger:

Värttinä's new live- $C D$, entitled 6.12., opens on a menacing note. As otherworldly instruments writhe and skirl demonically, vocalist Kirsi Kähkönen begins a guttural chant, spinning the tale of an elderly shaman called "Äijö" who unreels a terrifying curse on a snake in his garden. As Kähkönen's voice mounts to a frenzy, the three other vocalists join in behind her like Macbeth's weird sisters. The effect is riveting, and unlike anything ever recorded. (Stenger 2002, 24)

Stenger obviously has in mind the opening of the first scene of Act IV of Shakespeare's Macbeth. This scene includes what might be considered as the prototypical or even archetypical example of witchcraft: a cavern, a caldron boiling in the middle, thunder, and three witches reciting a spell (see Appendix 2). Tarte's reference to the brothers Grimm fits this setting well. In Walt Disney's adaptation of Snow White, there is, indeed, a scene taking place in a cavern, with a boiling caldron, witchcraft, thunder and spell recitation. It is, of course, the scene in which the bad Queen transforms herself into an old hag. The spell she reads in this scene goes as follows:

Mummy dust to make me old,

To shroud my clothes, black of night.

To age my voice, an old hag's cackle.

To whiten my hair, a scream of fright.

A blast of wind to fan my hate,

A thunderbolt to mix it well.

Now begin thy magic spell. (Dirks 2005)

It is certainly a matter of dispute whether Tarte actually had this scene in mind or whether he just referred to the darker side of the original versions of the Grimm-brothers' tale. It seems, in any case, that there was a tendency 
among Anglo-American critics to interpret “Äijö's" original reference to ancient Finno-Ugric shamanism according to commonly known Western texts dealing with fantasy, magic and witchcraft. This does not necessarily mean that the critics misread the song. On the contrary, the vivid descriptions provided by Stenger and Tarte fit the list of words with which Varilo "lamely" described his original vision of the song astonishingly well: a threat, a supernatural event, a trance, fear and the Middle Ages. The reviews also imply that Kähkönen succeeded perfectly in performing the spell-surely all the talk about "the girls from Rääkkylä" being unable to make a credible performance of the spell was premature and greatly exaggerated.

\section{LATER RECEPTION}

In December 2001, Värttinä Forum, an online chat site for fans and everyone interested in Värttinä, was opened. Everyone is free to read the messages sent to the Forum, but participating in the discussion requires registration. The site is controlled by the administrator who acts as a "gatekeeper" and often establishes new topics. There are active and passive participants; some of the active ones can be called opinion leaders. The Forum is divided into two sections, "discussion" and "albums." Both sections are further divided into files, each dealing with a specific topic or album. Comments concerning "Äijö" can be found mainly from the file dealing with the Live in Helsinki (6.12.) album (albums section) and from various files on the discussion section (including concert reviews and files concerning Finno-Ugric music and culture).

The discussion on the site demonstrates that the consumption of "Äijö," as well as Värttinä's music in general, is similar to popular music consumption: it takes place in various contexts, ranging from private situations (listening to records, watching TV or video) to public ones (attending concerts and club performances, chatting on the Internet). The fans exchange opinions about the song and its different versions-including different concert performances-on the Värttinä Forum. Once again the question to be examined here concerns the "chain" and "choice" relationships within discursive practices, even though the chains are not as settled here as they tend to be in production and distribution. As for "Äijö" however, one finds a curious pattern: several reports show that foreigners encountering the "Äijö" video or a concert broadcast on television, cannot relate it to anything, even though they are immediately hooked. A good example of this is provided by "Tom from Connecticut" (USA):

I first saw Värttina Saturday night. It was a video performance of incredible power, and I have spent this morning (when I should be working) trying to track down what I saw. I have downloaded a video performance but it does not seem to be quite the same one as I saw on television (the station was "Earthlink"); in particular, I thought a different one of the four women did most of the singing and chanting, but it seems likely there is 
only one video of the band performing the song. My questions are: is this video available in the USA? Is there more than one video? Is the song on both "Ilmatar" and " 6.12 " Any help would be greatly appreciated. It has been a LONG time since I was so blown away by a musical piece! (Värttinä Forum 2002a)

The same story is repeated in several other accounts, one of which is provided by "Iain" (Ontario, Canada): "This is the first Värttinä album I have bought. I'd never even heard of them until one night I was channel hopping and came across the 'Äijö' video. I have to say I fell for them hard. So, now I am the proud owner of 6.12" (Värttinä Forum 2002b).

Another version of the same story can be found in a customer review on Amazon.com, written by "kagirl" (Arizona, USA): "Sometimes, the best musical discoveries are made almost by accident. After hearing another Finnish group (Troka) perform on A Prairie Home Companion, I went in search of more information on the Web and came across an item about Värttinä performing at Rock in Rio-and bringing down the house. A brief sample or two later, and I bought the CD-now I'm hooked." The same site offers still another version provided by "A music fan" (Indiana, USA): "I first learned of Värttinä when I [saw] them perform 'Äijö' on World Music TV late one night. Being the Finnish afficianado [sic] that I am, I immediately looked them up and ordered this CD. I was really thrilled with it" (Amazon 2000)

One interesting aspect in these descriptions is that the emphasis is on the intensity of the experience itself, often at cost of the content. The fact that the music has a meaning seems to be more important than what it means in terms of its specific content. This is explicit in the following description provided by "Jérémie" (Lyon, France):

I've discovered the Värttinä music a few months ago, with the release of 6.12 , the live in Helsinki... This recording is a lollapalooza! I make music with few friends, and I've seen people say me thanks for the music I've made. I was happy because it gave me a good feel about me, and it gave me too the confirmation that I've found a good way to express myself, not with words, but with sounds without concrete meaning. And each one could give a meaning to these sounds. His own meaning. And no meaning is a meaning too! The meaning I gave to the "Värttinä sounds," which must be quite different of the Värttinä one, was really positive for me. Not naïve. But true. And it's very important for me. So, "Kiitokset" ["Thanks"] for this true music. It's rare in this world... Really really thanks. (Värttinä Forum 2002b)

It is also evident that the story about the first encounter with Värttinä through the "Äijö" video has become part of the common mythology the fans have constructed around the group. In "Markéta's" words, "I saw the video some time ago, I fell in love with it... and you know the end" (Värttinä Forum 2004). 
In addition to the performance at the Savoy Theatre on 6 December, 2000, there are two other performances in Helsinki that are worth mentioning here. On 2 May 2002-exactly two years after the first Finnish release of IlmatarVärttinä played once again at the Savoy Theatre. This time, Tarja Halonen, President of Finland, was sitting in the audience. The other performance was Värttinä's $20^{\text {th }}$ Anniversary concert at Alexander's Theatre on 28 February 2003. The date in question (28 February) is at the same time Kalevala's Day and the Day of Finnish Culture-certainly a suitable day for Värttinä to celebrate their $20^{\text {th }}$ Anniversary. This date also refers to a specific historical moment, which is the reason why it was chosen in the first place: Elias Lönnrot dated the preface to the Old Kalevala on 28 February 1835 (Honko 2003).

Finally one last point must be made concerning the stage production of The Lord of the Rings, mentioned at the beginning of this article. According to producer Kevin Wallace, the company turned to Värttinä because they needed "something to the dark side in the music, which is going to genuinely disturb an audience" (MTV3 2004). Musical supervisor Chris Nightingale reveals that the musical traditions they listened to before choosing Värttinä included Chinese music, Silk Road music, gypsy music, Middle Eastern music, Bulgarian music... Nightingale goes on:

And I have to say that it was immediately obvious that Värttinä would be the right band. There is one particular track on one of their albums that's called Ilmatar, and there's a track [sic] on it called "Äijö," which-we listened to it and were completely taken aback by ... because it represented everything we wanted in the music to be evil. (MTV3 2004)

These statements strike a common chord with Bob Tarte's conception of Värttinä being "the most elementally pagan sound in pop"; they also show how perfectly Wallace and Nightingale have captured the illocutionary force of "Äijö." The Lord of the Rings is, of course, just another well-known Western text with which "Äijö" and Värttinä's music has been associated. Interestingly, however, there is a well-grounded connection between Tolkien's The Lord of the Rings and the Finno-Ugric tradition. It is commonly known that Tolkien was inspired by the Kalevala and modeled the language of the Middle-earth elves partly according to the Finnish language, which he himself had come to understand. Even the name of Ilúvatar (Father of All) in Tolkien's Silmarillon may have been derived from Ilmatar, the Goddess of Air in the Kalevala and the title of Värttinä's eighth album. In the official press release of the stage production of The Lord of the Rings this was put in the following terms:

Värttinä, fronted by three female singers and supported by six acoustic musicians, are now celebrating their $20^{\text {th }}$ year and the release of their $10^{\text {th }}$ album. Since 1990, they have toured internationally and built a reputation as one of the most inventive and uncompromising ensembles in the contemporary world music arena. The original inspiration for Tolkien's stories and languages (such as Elvish), and for much of Värttinä's music 
and lyrics, is the Kalevala, Finland's national epic of mythological songs, poems and stories. (Värttinä Forum 2005)

No wonder that the producer and musical supervisor of the stage adaptation of The Lord of the Rings ended up in Finland to capture the right atmosphere. J.R.R. Tolkien himself had already done exactly the same. But whereas Tolkien drew from the Kalevala (Elias Lönnrot's compilation of Finno-Ugric runes), Wallace and Nightingale chose a group that draws directly from the original runes.

\section{Concluding Remarks}

The above analysis illustrates how the meaning (content, topic, subject matter) of a song like "Äijö" is constructed bit by bit during the production, distribution and consumption of its different versions. It also shows how different subject positions representing different stages of the process (production, promotion, criticism, consumption) result in different interpretations of the song and the albums containing it. The results support the assumption that critical discourse analysis (CDA) is in fact a suitable methodological framework for the analysis of cultural products such as "Äijö." Since the method, developed by Fairclough, puts strong emphasis on linguistics, it needs to be complemented with suitable methods from musicology and/or ethnomusicology.

To sum up, the bare starting point of "Äijö" is the "feel" (threat, fear, Middle Ages) of the melody. The lyrics provide an "inter-semiotic translation" of the "feeling" into a verbal narrative. The arrangement, in turn, provides the melody and lyrics with a kind of "soundtrack" consisting for example of a drone and a mix of ethnic instruments ranging from jouhikko (ancient Finnish bow lyre) to cümbüs tanbur (long-necked Turkish lute). In the recording studio, extra sound effects (including picking and sweeping of piano strings) are added to this "soundtrack." Rock singer Alanko is asked to do the spell-adding a "diegetic" dimension to the performance-and the spell itself is brought onto the surface in the final mix. Thus the original "illocutionary force" of the melody is strongly emphasized during the production of the song. The video is another "inter-semiotic translation": both the addition of the visual aspect and the screeching of the spell by Kähkönen increases further the force of the song.

The title of the song ("Äijö"), as well as the titles of the albums containing it (Ilmatar, 6.12./Live in Helsinki) act as "hermeneutic windows" on its meaning: they can be seen as citational inclusions that strongly emphasize Finno-Ugric and/or Finnish discourse. Ilmatar refers not only to the FinnoUgric rune song tradition but also to the Goddess of Air in the Finnish creation myth. The original title of Värttinä's live album (6.12.), in turn, is a citational inclusion that links the album (and the songs it contains) to the Independence Day of Finland (6 December) and, so doing, also emphasizes 
the position of Finland as an independent nation-state. This emphasis is enhanced further by President Tarja Halonen's presence at Värttinä's concert at the Savoy Theatre in May 2002 and by the fact that Värttinä chose to play their $20^{\text {th }}$ Anniversary concert at the Alexander Theatre on the Kalevala's Day, 2003 (the Day of Finnish Culture). This emphasis on cultural continuity can be seen as an example of the strengthening of cultural and national identity, and thereby the resistance to globalization.

In addition to Finno-Ugric or Finnish discourse, certain reviewers link Värttinä's music to other local (ethnic) music cultures, to global popular music or to world literature. Christina Roden (The Village Voice) throws in references to different traditions in time (Medieval) and place (Balkan, Russian, Galician, Celtic), as well as to global popular music ("Eleanor Rigby," Nina Simone). In spite of this, she mentions the significance of the rune song and even gives a short description of certain structural features. In this sense, her review can be seen as a negotiated interpretation of the album. NorthSide releases the live album in the USA and Canada under the title Live in Helsinki, thus omitting the reference to Finland's Independence Day. As there are no specific references to the Finno-Ugric rune tradition either, the mixed intertextuality of the music itself leaves room for loose associations ranging from ABBA to Macbeth and the tales of the brothers Grimm. The reference to $A B B A$ is further associated to the frequently used slogan "Bulgarian Voices meet ABBA," whereas the references to Macbeth and the brothers Grimm can be seen as attempts to understand the shamanistic aspects of "Äijö" in terms of allusions to witchcraft in well-known texts of Western literature. In this context however, it is interesting to notice that Jacob Grimm himself played a crucial role in the internationalization of the Finnish culture in the $19^{\text {th }}$ century with his favourable comments on the Kalevala.

The data also contains several reports of foreigners' encounters with the "Äijö" video or concert broadcasts on television. Though they cannot relate it to anything, they are none the less immediately hooked. This might be seen as an instance of what Hall calls a global post-modern experience: people who are far removed from one another in time and space can, "as 'customers' for the same goods, 'clients' for the same services, 'audiences' for the same messages and images", experience a kind of "shared identity" $(2003,302)$. Hall maintains that "it is unlikely that globalization will simply destroy national identities." More likely it will "produce, simultaneously, new 'global' and new 'local' identifications" (2003, 304; original italics). These new identities are likely to be hybrid, much in the same sense as Värttinä's music is.

The effect of Värttinä's music on international audiences is to a certain degree comparable to that of the Kalevala. Asplund and Mettomäki (2000b) have speculated on the question of why the Kalevala has been translated into so many other languages, even though its language is archaic, the poetic meter ancient and the Finnish cultural sphere relatively small. They assume that there are several possible explanations but single out three in particular. First, 
the Kalevala is part of the world's literature and, as such, capable of making "itself felt across the boundaries of space and time." Second, the impact of the Kalevala on Finnish national identity may inspire other peoples or ethnic groups "wishing to promote their own cultural self-awareness and national or ethnic independence." Third, the "northern exotism" of the epic is "merely a veneer which masks myths common to all peoples."

These three explanations, which seem to apply to Värttinä as well, can be viewed in relation to Hall's three hypothetical consequences of globalization $(1990,78)$. The first explanation is related to cultural homogenization by the inclusion of the Kalevala in world literature; it also seems to be about what Bauman and Briggs (1990) call "the internationalization of culture." The second of the explanations is clearly related to the strengthening of nationalist or other particularistic tendencies-whether by resistance to globalization or otherwise; this, in turn, seems to concern what Bauman and Briggs call "the nationalization of culture." The third explanation is perhaps the most interesting, because it seems to suggest that the experience of "shared identity," mentioned by Hall, is not only based on "the global post-modern experience" (that is, the experience of being exposed to same or similar goods, services or images) but also to "the myths common to all peoples."

The latter interpretation seems to explain the repeated story of the foreigner's first encounter with "Äijö" better than the one based on global post-modern experience. It also seems to explain why Anglo-American reviewers relate the Finno-Ugric shamanism of "Äijö" to Macbeth or to the tales of the brothers Grimm: "northern exotism" can be interpreted in terms of "western witchcraft" since the common denominator of both is the mythical relation of man to the supernatural. More generally, human beings can relate to each other in spite of language barriers and cultural differences since they share the common experience of being human. It is, indeed, this capacity that makes the transmission of a certain cultural tradition-say, the Finno-Ugric rune song - to a different cultural context possible. This is not to say, however, that Hall's three hypothetical attitudes toward globalization are not relevant; it only adds an extra dimension to the hypotheses concerning the global and new hybrid identities. Emphasizing cultural differences is characteristic of particularistic (ethnic, national, regional etc.) identities, based on distinguishing "us" from "them." Cultural homogenization and the formation of new hybrid identities (whether "global" or "local") seem to be based on similarities between people across language barriers and cultural differences. 
Appendix 1. The Structure of "Äijö" (the version on Ilmatar)

\begin{tabular}{llll}
\hline time & section & bars & description \\
\hline $0^{\prime} 00^{\prime \prime}$ & intro & - & noise (squeaks, squawks, drone) \\
$0^{\prime} 03^{\prime \prime}$ & & 3 & basic riff in modal E minor (noise continues) \\
$0^{\prime} 12^{\prime \prime}$ & 4 & basic riff + male vocals 1 (Ismo Alanko) \\
$0^{\prime} 23^{\prime \prime}$ & 5 & basic riff + male vocals 2 (Ismo Alanko) \\
\hline
\end{tabular}

\begin{tabular}{llll} 
0'38" & A1 & 4 & 1st minor type (modal E minor) \\
0'51" & A1 & 4 & " \\
1'01" & B1 & 4 & 2nd minor type (modal E minor) \\
1'13" & solo 1 & 4 & basic riff in modal E minor \\
1'24" & A1 & 4 & " \\
1'36" & B1 & 4 & as B1 above \\
1'47" & solo 2 & 4 & basic riff modal B minor \\
1'59" & A2 & 4 & bitonal (vocals as A1, backing as interlude 2) \\
2'11" & A2 & 4 & " \\
2'22" & B2 & 4 & new backing vocals and chord structure \\
2'34" & solo 3 & 4 & as interlude 2 above \\
\hline 2'45" & spell & 8 & first part (based on an original spell) \\
3'09" & & 8 & second part (with "lunatic" laughter overdub) \\
3'33" & & 4 & second part repeated (without laughter) \\
\hline 3'43" & B3 & 4 & backing vocals as in B2, new chord structure \\
3'55" & B3 & 4 & " \\
4'06" & A2 & 4 & bitonal (as A2 above) \\
4'18" & & & the "last gasp" of Äijö \\
\hline
\end{tabular}




\section{Appendix 2. Macbeth}

\section{ACT IV. SCENE I.}

A cavern. In the middle, a caldron boiling. Thunder. Enter the three witches

FIRST WITCH.

Round about the caldron go;

In the poison'd entrails throw.-

Toad, that under cold stone

Days and nights has thirty one

Swelter'd venom sleeping got,

Boil thou firts i'the charmed pot.

ALL.

Double, double toil and trouble;

Fire, burn; and caldron bubble.

SECOND WITCH.

Fillet of a fenny snake,

In the caldron boil and bake;

Eye of newt, and toe of frog,

Wool of bat, and tongue of dog,

Adder's fork, and blind-worm's sting,

Lizard's leg, and howlet's wing,-

For a charm of powerful trouble,

Like a hell-broth boil and bubble.

ALL.

Double, double toil and trouble;

Fire, burn; and caldron bubble.

\section{THIRD WITCH.}

Scale of dragon; tooth of wolf;

Witches' mummy; maw and gulf

On the ravind' salt-sea shark;

Root of hemlock digg'd i'the dark;

Liver of blasphemic Jew;

Gall of goat; and slops of yew

Silver'd in the moon's eclipse;

Nose of Turk, and Tartar's lips;

Finger of birth-strangled babe

Ditch-deliver'd by a drab,-

Make the gruel thick and slab:

Add thereto a tiger's chaudron,

For th'ingredients of our caldron.

ALL.

Double, double toil and trouble;

Fire, burn; and caldron bubble.

SECOND WITCH.

Cool it with a baboon's blood,

Then the charm is firm and good. (Shakespeare 1999, 873-874) 


\section{REFERENCE LIST}

Agawu, Kofi. 1999. "The Challenge of Semiotics." Rethinking Music, Nicholas Cook and Mark Everist ed. Oxford: Oxford University Press, 138-60.

Amazon.com. 2000. "Värttinä: Ilmatar," Amazon.com Reviews. http://www. amazon.com/exec/obidos/tg/detail/-/B0000584U6/103-7335141-9097 410 ? $v=$ glance $($ accessed 24 September 2002).

Asplund, Anneli. 1995. "Rune Songs from Finland, Karelia and Ingria." Sleeve notes in The Kalevala Heritage: Archive Recordings of Ancient Finnish Songs. Helsinki: Ondine ODE 849-2.

Asplund, Anneli, and Mettomäki, Sirkka-Liisa. 2000a. "The songs behind the Kalevala," On Virtual Finland: Kalevala - The Finnish National Epic. http://virtual.finland.fi/netcomm/news/showarticle.asp?intNWSAID= 27016 (accessed 29 January, 2005).

. 2000b. "The Kalevala around the World," On Virtual Finland: Kalevala - The Finnish National Epic. http://virtual.finland.fi/netcomm/ news/showarticle.asp?intNWSAID =27023 (accessed 29 January, 2005).

Bauman, Richard and Briggs, Charles L. 1990. "Poetics and Performance as Critical Perspectives on Language and Social Life." Annual Review of Anthropology 19, 59-88.

BMG. 2001. "BMG-uutuuksia 3/5/2001," BMG Finland. http://www.c lick2 music.fi/finland/viikkarit/vk35/vk35.htm (accessed 19 September, 2002).

Cho, John. 1996. "Fin de Siècle Music," RootsWorld (originally published in The San Juan Star in 1996). http://www.rootsworld.com/rw/finland/ varttina.html (accessed 30 January, 2003).

Click2Music. 2001. "Värttinä: Biography," Click2Music. http://www.click2 music.fi/biografi.asp?art=209 ('accessed 22 November, 2001).

Cronshaw, Andrew. 2000. "Värttinä: Ilmatar." Folk Roots 22/4: 54. . 2001. "Beating Varts." Folk Roots 22/11: 41-43.

DFG-NRW. 1998. "Värttinä: Vihma Tour 1998-Deutschland," Deutsch-Finnisch Gesellschaft Nordrhein-Westfalen-Värttinä. <http://members.aol. com/dfgnrw/vaerttin.htm > (accessed 30 January, 2003).

Dirks, Tim (2005) "Snow White and The Seven Dwarfs (1937)," Greatest Films. http://www.filmsite.org/snow.html (accessed 22 January, 2005)

Fairclough, Norman. 1998. Discourse and Social Change. Cambridge: Polity Press.

1999. Critical Discourse Analysis: The Critical Study of Language. London: Longman.

Franzen, Stefan. 2003. ''Iki' von Värttinä-Folkrock aus Finnland der Spass macht," Amazon.de. http://www.amazon.de/execobidos/ASIN/ B00008CQX8/308-1388508-1527205 (accessed 30 October, 2004).

Graham, George. 1996. "Värttinä: Kokko," The Graham Weekly Album Reviews, \#1049 (originally broadcast on WVIA-FM 11/27/96). http:// georgegraham.com/värttinä.html (accessed 30 October, 2004). 
Hall, Stuart. 1980. "Encoding/decoding." Culture, Media, Language: Working Papers in Cultural Studies, 1972-79. Stuart Hall, Dorothy Hobson, Andrew Lowe, and Paul Willis eds. London: Hutchinson in association with the Centre for Contemporary Cultural Studies / University of Birmingham, 128-138.

. 2003. "The Question of Cultural Identity." Modernity and Its Futures, Stuart Hall, David Held, and Tony McGrew eds. Cambridge: Polity Press, 273-326.

Hemmi, Risto. 2002. Telephone interview: 18 December, 2002.

Hirsch, Paul M. 1990. "Processing Fads and Fashions: An Organization-Set Analysis of Cultural Industry Systems." On Record: Rock, Pop, and the Written Word. Simon Frith and Andrew Goodwin eds. London: Routledge, 127-139.

Honko, Lauri. 2003. "The five performances of the Kalevala," Fellows for Folklore Network. <http://www.folklorefellows.fi/netw/ffn24/five_performances. html (accessed 29 January 2005).

Indigo. 2004. "Värttinä: 6.12.(Live)," Indigo. http://www.indigo.de/unser_ programm/titel/0951/ (accessed 30 October, 2004).

Kähkönen, Kirsi. 2002. Telephone interview: 18 December, 2002.

Karpeles, Maud. 1973. An Introduction to English Folk Song. London: Oxford University Press.

Kotirinta, Pirkko. 2000. "Akustista ilmaa siipien alle - Ilmatar esittelee kypsyneen Värttinän," Helsingin Sanomat, 2 May, 2000. http://www. helsinginsanomat.fi/arkisto/juttu.asp id $=20000502 \mathrm{KU} 3$ (accessed 13 December, 2002).

Kramer, Lawrence. 1990. Music as Cultural Practice, 1800-1900. Berkeley: University of California Press.

Launis, Armas, ed. 1910. Suomen Kansan Sävelmiä IV Jakso. Runosävelmiä 1. Inkerin runosävelmät. Helsinki: Suomalaisen Kirjallisuuden Seura.

Leone, Dominique. 2003. "Värttinä: Iki," Pitchfork Media, 23 May 2003. http://www.pitchforkmedia.com/record-reviews/v/varttina/iki.shtml (a ccessed 30 October, 2004).

Nevalainen, Kimmo. 2001. Värttinä: Korkeelta ja kovvoo: Historia, musiikki ja nuotit. Like: Helsinki.

Nickson, Chris. 2002. "Värttinä: Ilmatar," Barnes \& Noble Reviews. http:// music.barnesandnoble.com/search/product.asp?userid=0MXXBBQYV J\&wrk =5 017125 (accessed 24 September, 2002). Originally issued in AMG (All Music Guide).

.2003a. "Värttina Finish Finnish Myth Cycle With Ilmitar [sic]. Band's eighth album nearly lost to contractual limbo," VH1.COM. http:// www.vh1online.com/artists/news/1439320/02122001/varttina.jhtml (accessed 16 January, 2003).

. 2003b. "Värttinä: Ilmatar," Mondomix Reviews. http://mondomix. org/mix_us/reviews_us/reviews_artists/ilmatar.htm (accessed 21 January, 2003). 
NorthSide. 2002. "Live in Helsinki by Värttinä," NorthSide. http://www. noside.com/Catalog/CatalogAlbum_01.asp?Album_ID=164 (accessed 19 September, 2002).

. 2004. "Seleniko by Värttinä," NorthSide. http://www.noside.com/ Catalog/Catalog/Album_01.asp?Action=GetOne\&Album_ID=99 (accessed 30 October, 2004).

Rekinen, Jyri-Jussi. 2000. "Värttinä manaa Ilmattaren loitsuja," Rytmi 3/2000. http://www.rytmi.com/rytmi300/3varttinamanaa.html (accessed 22 November, 2001).

Roden, Christina. 2000a. "Värttinä-And the Goddess of Air," CMJ, http://www.cmj.com/articles/display_article.php?id=30341 (accessed 22 January, 2005).

2000b. "Värttinä, Ilmatar," RootsWorld Reviews. http://www. rootsworld.com/reviews/ilmatar.shtml (accessed 30 September, 2002).

Shakespeare, William. 1999. Macbeth. The Complete Works of William Shakespeare (The Shakespeare Head Press Edition). Hertfordshire: Wordsworth, 858-84.

Stenger, Wif. 2002. "Ancient Roots-Bright New Shoots." Blue Wings (February-March): 24-25.

Tarte, Bob. 2002. "Värttinä, Wimme-Live in Helsinki, Gierran, Cugu," Miami New Times, 2.5.2002. http://www.miaminewtimes.com/issues/ 2002-05-02/smallworld.html/print.html (accessed 24 September, 2002).

Varilo, Antto. 2002. E-mail interview. Questions sent: 18 December, 2002. Answers received: 22 December, 2002.

Värttinä. 2001a. Ilmatar. BMG, (RCA) CD 74321881792. . 2001b. 6.12. BMG, CD 743218818038.

. 2002. "Värttinä-'Äijö'," Video info. http://www.varttina.com/ videos/ (accessed 13 December, 2002).

. 2005. "Evolution," http://www.varttina.com/evolution/ Last revised: December 20, 2004 (accessed 2 February, 2005).

Värttinä Forum. 2002a. "Confusion about Äijö," Värttinä Forum. http:// forum.varttina.net/cgi-bin/ultimatebb.cgi?ubb=get_topic\&f $=17 \& t=00$ 0003 (accessed 5 December, 2002).

. 2002b. "Fans Around the World: Thanks Värttinä!," Värttinä Forum. http://forum.varttina.net/cgi-bin/ultimatebb.cgi?ubb=get_topic $\& \mathrm{f}=1 \&$ $\mathrm{t}=000013$ (accessed 5 December, 2002).

. 2004. "Prague, 14 March 2004," Värttinä Forum. http://forum. varttina.net/cgi-bin/ultimatebb.cgi?ubb=get_topic $\& f=3 \& t=000051$ (accessed 21 October, 2004).

. 2005. "The Lord of the Rings Musical: Press Release," Värttinä Forum. http://forum.varttina.net/cgi-bin/ultimatebb.cgi?ubb=get_topic $\& \mathrm{f}=21$ $\& \mathrm{t}=000003$ (accessed 2 February, 2005). 


\begin{abstract}
Contemporary Finnish folk music, unlike internationally successful contemporary Finnish rock (HIM, Nightwish, The Rasmus), transmits Finnish and Finno-Ugric tradition in a reinterpreted form to international audiences. This article explores this transmission through a case analysis of Äijö, a song by Värttinä, "the brand name" of Finnish World Music. Critical Discourse Analysis (CDA) provides a unified framework, which allows for tan examination of how different folk music traditions and the practices of Western popular music have been used in Äijö. The data with which this research was undertaken consists of publicly available media texts representing different stages of the production, distribution and consumption of Äijö.
\end{abstract}

\title{
RESUME
}

Contrairement au très populaire rock finnois (HIM, Nightwish, The Rasmus), la musique folklorique contemporaine finnoise transmet la tradition finnoise et finno-ougrienne - sous une forme réinterprétée - à des publics internationaux. Cet article explore cette transmission par une analyse de cas, en l'occurrence celui de Äijö, une chanson de Värttinä, la " marque par excellence » de la world music finnoise. L'analyse critique du discours offre un cadre unificateur permettant d'examiner l'apport des différentes traditions folkloriques musicales et des pratiques de la musique populaire occidentale dans l'élaboration de Äijö. Les données utilisées pour cette recherche sont essentiellement constituées de textes médiatiques publics représentant différentes étapes de la production, de la distribution et de la consommation de Äijö. 